\title{
Effect of Fly Ash and Phosphorus on Growth and Yield of Bt Cotton (Gossypium hirustum L.)
}

\author{
Inderpreet Singh, Balwinder Singh Dhillon* and Mandeep Kaur
}

College of Agriculture, Guru Kashi University, Talwandi Sabo, Punjab, India

*Corresponding author

\section{A B S T R A C T}

\section{Keywords}

Bt cotton, Fly ash, Phosphorous, Seed cotton yield, Stalk yield and Sympodial branches

\section{Article Info}

Accepted:

15 December 2020 Available Online: 10 January 2021
A field experiment entitled "Effect of fly ash and phosphorus on growth and yield of Bt cotton (Gossypium hirustum L.)" was conducted during kharif 2018 at Research Farm, Guru Kashi University, Talwandi Sabo, Bathinda (Punjab). The experiment was laid out in split plot design comprising two fly ash doses viz., control (0 t/ha) and $10 \mathrm{t} / \mathrm{ha}$ in main plots and four doses of phosphorous viz., 0, 20, 30 and $40 \mathrm{~kg} \mathrm{P}_{2} \mathrm{O}_{5} / \mathrm{ha} \mathrm{kg} / \mathrm{ha}$ in sub plots. The results showed that the highest plant growth viz., dry matter production and leaf area index and yield attributing characters viz., number of sympodial branches/plant, number of bolls/plant and stalk yield was recorded in fly ash @ 10 t/ha which was significantly higher over the control. The higher seed cotton yield was recorded with the application of fly ash@10 t/ha which was significantly higher over the control. With application of fly ash recorded 6.62\% more seed cotton yield than control. Phosphorous @ $40 \mathrm{~kg} \mathrm{P}_{2} \mathrm{O}_{5} / \mathrm{ha}$ recorded the highest plant height, dry matter, leaf area index, number of sympodial branches/plant, boll weight and stalk yield which was statistically at par with $30 \mathrm{~kg}$ $\mathrm{P}_{2} \mathrm{O}_{5} /$ ha and was significantly higher than control $\left(0 \mathrm{~kg} \mathrm{P}_{2} \mathrm{O}_{5} / \mathrm{ha}\right)$ and $20 \mathrm{~kg} \mathrm{P}_{2} \mathrm{O}_{5} / \mathrm{ha}$. The highest seed cotton yield (19.2 q/ha) was obtained in $40 \mathrm{~kg} \mathrm{P}_{2} \mathrm{O}_{5} / \mathrm{ha}$ which was significantly higher than other phosphorous levels viz., $0 \mathrm{~kg} \mathrm{P}_{2} \mathrm{O}_{5} / \mathrm{ha}(9.9 \mathrm{q} / \mathrm{ha})$ and $20 \mathrm{~kg}$ $\mathrm{P}_{2} \mathrm{O}_{5} /$ ha $(15.2 \mathrm{q} / \mathrm{ha})$, but it was statistically at par with $30 \mathrm{~kg} \mathrm{P}_{2} \mathrm{O}_{5} / \mathrm{ha}(18.1 \mathrm{q} / \mathrm{ha})$. Phosphorous@ $30 \mathrm{~kg} \mathrm{P}_{2} \mathrm{O}_{5} / \mathrm{ha}$ and $40 \mathrm{~kg} \mathrm{P}_{2} \mathrm{O}_{5} /$ ha recorded 82.8 and $93.9 \%$, respectively higher seed cotton yield than $0 \mathrm{~kg} \mathrm{P}_{2} \mathrm{O}_{5} /$ ha in $\mathrm{Bt}$ cotton.

\section{Introduction}

American cotton (Gossypium hirustum L.) also known as "upland cotton" originated in South America, is most widely cultivated fiber crop of the world and contributes about 95\% of the approximately 110 million bales of cotton produced throughout the world. It is an important cash crop known as white gold and is also known as the king of fiber crops.
In India, cotton is grown under diverse agroclimatic conditions and contributes nearly $65 \%$ of total raw material needs of the textile industry. It plays a major role in India's economy, both in terms of providing employment directly or indirectly to about 60 million people and in production of wealth and earning foreign exchange for the country to the tune of ' 60,000 crores (Anonymous, 2018a). In India, it was cultivated on an area 
of $11.16 \mathrm{~m}$ ha with a production of 31.20 million bales of seed cotton during 2017-18. Its average productivity in India was $494 \mathrm{~kg}$ lint/ha, which was low as compared to world average of $725 \mathrm{~kg}$ lint/ha (Anonymous, 2018a). Maharashtra, Gujarat, Andhra Pradesh, Madhya Pradesh, Punjab, Haryana, Karnataka, Rajasthan and Tamil Nadu are the important cotton growing states in India. It was cultivated on an area of 2.87 lakh ha with a production of 12.71 lakh bales of seed cotton and productivity was $753 \mathrm{~kg}$ lint/ha during 2017-18 in Punjab (Anonymous, 2019b).

India ranks first in the world with respect to area under cultivation. This being the important cash crop of the country benefits several million people by providing employment opportunities i.e. cultivation, trade, manufacturing, processing. It is not a source of fiber only, but also a good source of edible oil, which play an important role to meet the demand of ever increasing population of India. Besides this, this crop also provides fuel for different purposes. Four species of the genus gossypium viz. hirustum, barbadense, arboreum and harbaceum are cultivated; hirustum occupies the first place (Anonymous 2020a).

In Punjab, intensive agriculture and dominating rice-wheat cropping system has created many problems like depleting of soil water, weed infestation and deterioration in soil health, attack of insect pests, diseases, and intensive use of energy and marketing problems through it contributes major food grains in control pest. Fly ash is a resultant waste produced from the combustion of coal in thermal power plants. Fly ash constitutes over $70 \%$ of the total quantity of residues produced in thermal power plants. Because such a large amount of fly ash is generated each year, a great deal of research needs to be conducted to determine the feasibility of its utilization in agriculture, construction and other industries. Rough estimates of existing utilization are around $10 \%$ of the total fly ash generated as against 3-5\%. Hence fly ash is now treated as a valuable resource due established viable avenues of fly ash management. According to the Central Electricity Authority (New Delhi), the total generated fly ash during 2010-11 was 66.49 million tonnes and its utilization was $54.23 \%$. Presence of various elements such as $\mathrm{P}, \mathrm{K}$, $\mathrm{Ca}, \mathrm{Mg}, \mathrm{S}$ and micronutrients in the fly ash make it a good source of plant nutrients (Deshmukh et al., 2000). The increased yield of different crops due to application of fly ash was observed by Kuchanwar and Matte (1997).

Phosphorus determines plant reproductive efficiency and play a vital role in growth and development of groundnut crop. The higher availability of phosphorus improved the physical environment with this treatment have contributed to higher yields of rice and wheat in successive years of reclaimination. Phosphorus (P) is the second major essential nutrient element for crop growth and good quality yield. The most obvious effect of $\mathrm{P}$ is on the plant root system. The requirement of $\mathrm{P}$ in nodulating legumes is higher compared to non-modulating crops as it plays a significant role in nodule formation and fixation of atmospheric nitrogen (Brady and Well, 2002). Due to the important role played by $\mathrm{P}$ in the physiological processes of plants, application of $\mathrm{P}$ to soil deficient in this nutrient leads to increase groundnut yield.

The earlier studies revealed that various levels of phosphorus application showed significant increase in both growth as well as yield attributes of Bt cotton under different climatic conditions. However, little information is available on effect of fly ash application on performance of Bt cotton crop. Thus keeping these points in view the experiment on 
"Effect of different doses of fly ash and phosphorus on growth and yield of Bt cotton (Gossypium hirustum L)" was undertaken.

\section{Materials and Methods}

The present investigation entitled "Effect of fly ash and phosphorus on growth and yield of Bt cotton (Gossypium hirustum L)" was conducted at Research Farm, University College of Agriculture, Guru Kashi University, Talwandi Sabo, Bathinda during Kharif 2018. Talwandi Sabo (Bathinda) is situated at $29^{\circ} 33^{\prime} \mathrm{N}$ latitude and $74^{\circ} 38^{\prime} \mathrm{E}$ longitude at a height of 208 metres above the mean sea level.

The experimental site belongs to semi-arid climate, where both summers and winters are acute. A maximum temperature of about $45^{\circ} \mathrm{C}$ is common during summer, while freezing temperature accompanied by frost happening may be there in the months of December and January. The monsoon normally starts from the first week of July.

The average annual rainfall at Bathinda is $500-750 \mathrm{~mm}$, most of which is received during the rainy season from July to September due to the south-west monsoons. Often, scanty rainfall is received during winter months of December, January and February. The experimental field tested low in organic carbon and available nitrogen, medium in available potassium and high in available phosphorus. The soil $\mathrm{pH}$ and electrical conductivity values were within the normal range.

The plant height was measured from each plot of the five different tagged plants at the time of maturity. It was taken from the base of the plant at ground level to the tip of plant and expressed as average plant height in $\mathrm{cm}$. The dry matter accumulation was recorded at maturity. The plant biomass collected from each individual plots was first dried under shade and then oven dried at $65^{\circ} \mathrm{C}$ till constant weight was observed. The data was expressed in $\mathrm{q} / \mathrm{ha}$. The leaf area index was recorded at maturity. The observations were recorded from each plot and the area of each leaf blade was calculated by using the formula given by Gomek (1972).

$$
\text { Leaf area index }=\underset{\text { Ground area }}{\stackrel{\text { Leaf area }}{\longleftarrow}}
$$

The flower bearing branches were counted from the five selected plant, which bear flowers at each node and average number of sympodial branches/plant was calculated. The numbers of bolls/plant was counted from each plot of the five different tagged plants.

The mean values were expressed as number of bolls/plant. The boll weight for five well opened balls was taken from each tagged plant after with the help of electric balance and mean value was calculated. The total seed cotton was harvested in two pickings.

The seed cotton picking from net plot was weighed separately. The sum of seed cotton per plot picked at different pickings was used for working out seed cotton yield/ha. The total weight of crop biomass from each plot was weighed separately and stalk yield in $\mathrm{kg} /$ plot was calculated and converted it into $\mathrm{q} /$ ha. The biological yield obtained from the addition of seed cotton yield and stalk yield.

Biological yield $=$ Seed cotton yield + Stalk yield

HI was calculated by dividing economic (Seed cotton) yield by the total biological (Seed cotton + stalk) yield and expressed as percentage.

$$
\mathrm{HI}(\%)=\frac{\text { Economic yield (Seed cotton) }}{\text { Biological yield (Seed cotton+ Stalk) }} \times 100
$$




\section{Results and Discussion}

\section{Growth parameters of Bt cotton}

The plant height is an important parameter of plant growth. The data related to plant height of Bt cotton was recorded at maturity and have been presented in Table 1. There was non-significant effect of different fly ash doses on plant height of Bt cotton.

Plant height $(210.3 \mathrm{~cm})$ was highest in $40 \mathrm{~kg}$ $\mathrm{P}_{2} \mathrm{O}_{5} /$ ha, which was significantly higher than control and $20 \mathrm{~kg} \mathrm{P}_{2} \mathrm{O}_{5} / \mathrm{ha}$, but it was statistically at par with $30 \mathrm{~kg} \mathrm{P}_{2} \mathrm{O}_{5} / \mathrm{ha}$. This consummate effect of phosphorous (P) fertilization on growth virtue of $\mathrm{Bt}$ cotton might be due to it decisive role in voluminous root development which facilitate the crop to excerpt water and minerals from deeper zones. Moreover, $\mathrm{P}$ is required for mitochondrial and symbioses membrane synthesis during nodule development to enhance nitrogen fixation. Thus, the enhanced nutrient availability boosted up nutrient uptake which consequently prompts vigorous plant growth and development. These results corroborate with the findings of Singh et al., (2006), Bhuiyan et al., (2008), Rotaru et al., (2009), Kokani et al., (2013) and Tomar et al., (2013).The interaction effect between fly ash and phosphorous doses on plant height of Bt cotton was found to be non-significant.

Dry matter accumulation is one of the most important parameter and has a marked influence on final yield realization of a crop. Data pertaining to dry matter accumulation of Bt cotton at 120 days after sowing (DAS) have been presented in Table 1 indicated that the application of fly ash significantly increased the dry matter production in $\mathrm{Bt}$ cotton. The highest dry matter production was recorded with the application of fly ash @ 10 t/ha which was significantly higher over the control. The better growth under fly ash application may be apparently due to the presence of utilizable plant nutrients in fly ash (Ghuman et al., 1994). Similar results also reported by (Matte and Kene 1995). The effect of phosphorus on the dry matter accumulation of $\mathrm{Bt}$ cotton was found to be positive and significant. Highest dry matter accumulation was recorded under $\mathrm{P}_{2} \mathrm{O}_{5}$ applied at the rate of $40 \mathrm{~kg} / \mathrm{ha}$ which was significantly higher than control $\left(0 \mathrm{~kg} \mathrm{ha}^{-1}\right)$ and $20 \mathrm{~kg} \mathrm{P}_{2} \mathrm{O}_{5} / \mathrm{ha}$ and but it was statistically at par with $30 \mathrm{~kg} \mathrm{P}_{2} \mathrm{O}_{5} / \mathrm{ha}$. The increases in dry weight due to $\mathrm{P}$ application may be attributable to the fact that $\mathrm{P}$ is known to help in the development of more extensive root system and nodulation, and thus enables plants to absorb more water and nutrients from depth of the soil. This in turn could enhance the plant's ability to produce more assimilates which were reflected in the high dry weight. Similar results have been reported by El- Habbasha et al., (2005) and Gobarah et al., (2006). The root growth of BT cotton plants was best at $40 \mathrm{~kg} \mathrm{P}_{2} \mathrm{O}_{5} /$ ha level which resulted in best dry matter accumulation due to efficient photosynthesis and other physiological functions at this $\mathrm{P}$ level. The dry matter accumulation/plant was the lowest in the control crop. The interaction effect between fly ash and phosphorus doses also found non-significant effect on dry matter production of Bt cotton.

The results pertaining to leaf area index of $\mathrm{Bt}$ cotton have been presented in Table1. Leaf area index was significantly influenced by fly ash application. The highest leaf area index was recorded with the application of fly ash @ 10t/ha, which was significantly higher than control. With the application of fly ash recorded (0.09) more leaf area index than control. This may be availability of nutrients in soil due to the application of fly ash resulted in more plant height, better development and more number of leaves. The highest leaf area index was found in $40 \mathrm{~kg}$ $\mathrm{P}_{2} \mathrm{O}_{5} /$ ha, being statistically at par with $30 \mathrm{~kg}$ $\mathrm{P}_{2} \mathrm{O}_{5} /$ ha and significantly higher than control 
$\left(0 \mathrm{~kg} \mathrm{P}_{2} \mathrm{O}_{5} / \mathrm{ha}\right)$ and $20 \mathrm{~kg} \mathrm{P}_{2} \mathrm{O}_{5} / \mathrm{ha}$. The lowest leaf area index was found from the treatment applied with no phosphorous fertilizer. It may also be due to the fact that optimum availability of phosphorous has been associated with increased rapid growth and development, thus those plots which received optimum phosphorous resulted more leaf area index as compared to control plots. The interaction effect between fly ash and phosphorous doses on leaf area index was found to be non-significant.

Table.1 Effect of different doses of fly ash and phosphorus on growth attributes of Bt cotton

\begin{tabular}{|c|c|c|c|}
\hline Treatments & $\begin{array}{c}\text { Plant height } \\
(\mathbf{c m})\end{array}$ & $\begin{array}{c}\text { Dry matter } \\
\text { accumulation (q/ha) }\end{array}$ & $\begin{array}{c}\text { Leaf area } \\
\text { index }\end{array}$ \\
\hline Fly ash doses (t/ha) & & & \\
\hline $\mathbf{0}$ & 192.5 & 19.8 & 2.14 \\
\hline $\mathbf{1 0}$ & 201.4 & 21.5 & 2.23 \\
\hline CD (p=0.05) & $\mathrm{NS}$ & 0.8 & 0.05 \\
\hline $\begin{array}{c}\text { Phosphorus doses } \\
\text { (kg/ha) }\end{array}$ & & & \\
\hline $\mathbf{0}$ & 180.8 & 17.5 & 2.06 \\
\hline $\mathbf{2 0}$ & 196.0 & 20.0 & 2.16 \\
\hline $\mathbf{3 0}$ & 200.8 & 21.7 & 2.22 \\
\hline $\mathbf{4 0}$ & 210.3 & 23.4 & 2.31 \\
\hline CD (p=0.05) & 11.5 & 1.8 & 0.09 \\
\hline Interaction & $\mathrm{NS}$ & $\mathrm{NS}$ & $\mathrm{NS}$ \\
\hline
\end{tabular}

Table.2 Effect of different doses of fly ash and phosphorus on yield attributes of Bt cotton

\begin{tabular}{|c|c|c|c|}
\hline Treatments & $\begin{array}{c}\text { No. of sympodial } \\
\text { branches/plant }\end{array}$ & $\begin{array}{c}\text { No. of } \\
\text { bolls/plant }\end{array}$ & Boll weight (g) \\
\hline Fly ash doses (t/ha) & & & \\
\hline $\mathbf{0}$ & 30 & 43.5 & 4.79 \\
\hline $\mathbf{1 0}$ & 32.6 & 52.5 & 4.92 \\
\hline CD (p=0.05) & 0.8 & 2.0 & NS \\
\hline $\begin{array}{c}\text { Phosphorus doses } \\
\text { (kg/ha) }\end{array}$ & & & \\
\hline $\mathbf{0}$ & 26.0 & 39.4 & 4.66 \\
\hline $\mathbf{2 0}$ & 30.6 & 46.9 & 4.80 \\
\hline $\mathbf{3 0}$ & 33.4 & 51.0 & 4.91 \\
\hline $\mathbf{4 0}$ & 35.3 & 54.7 & 5.06 \\
\hline CD (p=0.05) & 3.5 & 4.8 & 0.18 \\
\hline Interaction & NS & NS & NS \\
\hline
\end{tabular}


Table.3 Effect of different doses of fly ash and phosphorus on seed cotton yield, stalk yield and harvest index of $\mathrm{Bt}$ cotton

\begin{tabular}{|c|c|c|c|c|}
\hline Treatments & $\begin{array}{c}\text { Seed cotton } \\
\text { yield (q/ha) }\end{array}$ & $\begin{array}{c}\text { Stalk yield } \\
(\mathbf{q} / \mathbf{h a})\end{array}$ & $\begin{array}{c}\text { Biological } \\
\text { yield (q/ha) }\end{array}$ & $\begin{array}{c}\text { Harvest index } \\
\mathbf{( \% )}\end{array}$ \\
\hline $\begin{array}{l}\text { Fly ash doses } \\
\text { (t/ha) }\end{array}$ & & & & \\
\hline $\mathbf{0}$ & 15.1 & 23.5 & 38.6 & 38.6 \\
\hline $\mathbf{1 0}$ & 16.1 & 26.1 & 42.2 & 37.9 \\
\hline CD (p=0.05) & 0.8 & 1.6 & 1.1 & NS \\
\hline $\begin{array}{c}\text { Phosphorus } \\
\text { doses (kg/ha) }\end{array}$ & & & & \\
\hline $\mathbf{0}$ & 9.9 & 18.6 & 28.5 & 34.8 \\
\hline $\mathbf{2 0}$ & 15.2 & 24.6 & 39.8 & 38.3 \\
\hline $\mathbf{3 0}$ & 18.1 & 27.1 & 45.2 & 40.1 \\
\hline $\mathbf{4 0}$ & 19.2 & 29.1 & 48.2 & 39.8 \\
\hline CD (p=0.05) & 2.1 & 2.8 & 1.3 & 0.5 \\
\hline Interaction & NS & NS & NS & NS \\
\hline
\end{tabular}

\section{Yield parameters of Bt cotton}

The data related to number of sympodial branches/plant in $\mathrm{Bt}$ cotton have been presented in Table 2. The data indicated that the effect of application of fly ash significantly increased the number of sympodial branches/plant over the control. The highest number of sympodial branches/plant was recorded with the application of fly ash @ $10 \mathrm{t} / \mathrm{ha}$, which was significantly higher than control. Adequate supply of different plant nutrients with the application of fly ash increased the number of sympodial branches/plant in $\mathrm{Bt}$ cotton. Phosphorous @ $40 \mathrm{~kg} \mathrm{P}_{2} \mathrm{O}_{5} /$ ha recorded the highest number of sympodial branches/plant which was statistically at par with $30 \mathrm{~kg}$ $\mathrm{P}_{2} \mathrm{O}_{5} /$ ha and was significantly higher than control $\left(0 \mathrm{~kg} \mathrm{P} \mathrm{P}_{2} \mathrm{O}_{5} / \mathrm{ha}\right)$ and $20 \mathrm{~kg} \mathrm{P}_{2} \mathrm{O}_{5} / \mathrm{ha}$. It might be due to the fact that optimum availability of phosphorous has been associated with increased rapid growth and development, thus those plots which received higher phosphorous produced more number of sympodial branches/plant as compared to less phosphorous plots. The interaction effect between fly ash and phosphorous doses found to be non-significant effect on number of sympodial branches/plant in Bt cotton.

Data regarding number of bolls/plant have been presented in Table. 2 indicated that the number of bolls/plant of $\mathrm{Bt}$ cotton was influenced significantly by the fly ash. The highest number of bolls/plant was recorded in fly ash @ 10 t/ha treatment which was significantly higher over the control. With the application of fly ash recorded $20.7 \%$ higher bolls/plant than control. Application of fly ash improve the root activity of plants resulted in more nutrients supply therefore increased the number of bolls/plant in Bt cotton. Application of graded level of phosphorus significantly upgraded the number of bolls/plant in Bt cotton. The highest number of bolls/plant (54.7) was recorded in $40 \mathrm{~kg}$ $\mathrm{P}_{2} \mathrm{O}_{5} /$ ha treatment and it was significantly higher than control and $20 \mathrm{~kg} \mathrm{P}_{2} \mathrm{O}_{5} / \mathrm{ha}$ treatment, but it was statistically at par with $30 \mathrm{~kg} \mathrm{P}_{2} \mathrm{O}_{5} / \mathrm{ha}$. The lowest number of bolls/plant (39.4) was found in the control (0 $\left.\mathrm{kg} \mathrm{P}_{2} \mathrm{O}_{5} / \mathrm{ha}\right)$ treatment. The interaction between fly ash and phosphorous doses was 
also found non-significant effect on number of bolls/plant in Bt cotton.

Boll weight is an important parameter of yield. The data regarding boll weight of $\mathrm{Bt}$ cotton have been presented in Table 2. The data indicated that the effect of fly ash on boll weight was found to be non-significant. The highest boll weight was recorded with the application of $40 \mathrm{~kg} \mathrm{P}_{2} \mathrm{O}_{5} / \mathrm{ha}$ which was significantly higher than control and $20 \mathrm{~kg}$ $\mathrm{P}_{2} \mathrm{O}_{5} /$ ha, but it was statistically at par with 30 $\mathrm{kg} \mathrm{P}_{2} \mathrm{O}_{5} /$ ha. While the lowest boll weight was registered with $0 \mathrm{~kg} \mathrm{P}_{2} \mathrm{O}_{5} /$ ha. The propitious outcome was due to regulatory function of $\mathrm{P}$ in photosynthesis that escalates carbohydrate accumulation and sugar metabolism. It also coordinates starch: sucrose ratio and governs proper mobilization of photosynthates that lead to increased boll weight. Similar results were also reported by Nadeem et al., (2004), Sepat et al., (2005), Biswas et al., (2009) and Khan et al., (2017). The interaction effect between fly ash and phosphorous doses on boll weight found to be non-significant.

Data regarding seed cotton yield have been presented in Table 3. The data indicated that the seed cotton yield influenced by the fly ash application. The higher seed cotton yield was recorded with the application of fly ash @ 10 t/ha which was significantly higher over the control. With application of fly ash recorded $6.62 \%$ more seed cotton yield than control. This may be due to increasing the yield attributes characters with the application of fly ash resulted in more seed cotton yield. Similar results were also reported by Saini et al., (2010). Singh and Singh (1986) reported similar results for cotton and wheat grain yield with $20 \%$ fly ash which increased N, P and $\mathrm{K}$ nutrients and increased the growth and grain yield. The increase in plant height, number of branches/plant, number of bolls/plant and boll weight may be attributed to better moisture condition, nutrient absorption by the plant under fly ash application. Further perusal of the data revealed that seed cotton yield of Bt cotton varied significantly due to phosphorous doses. The highest seed cotton yield (19.2 q/ha) was obtained in $40 \mathrm{~kg} \mathrm{P}_{2} \mathrm{O}_{5} / \mathrm{ha}$ which was significantly higher than other phosphorous levels viz., $0 \mathrm{~kg} \mathrm{P}_{2} \mathrm{O}_{5} / \mathrm{ha}(9.9 \mathrm{q} / \mathrm{ha})$ and $20 \mathrm{~kg}$ $\mathrm{P}_{2} \mathrm{O}_{5} /$ ha $(15.2 \mathrm{q} / \mathrm{ha})$, but it was statistically at par with $30 \mathrm{~kg} \mathrm{P}_{2} \mathrm{O}_{5} / \mathrm{ha}(18.1 \mathrm{q} / \mathrm{ha})$. The lowest seed cotton yield obtained was in control $\left(0 \mathrm{~kg} \mathrm{P}_{2} \mathrm{O}_{5} \mathrm{ha}^{-1}\right)$. Phosphorous $\left(\mathrm{P}_{2} \mathrm{O}_{5}\right)$ @ $30 \mathrm{~kg} \mathrm{ha}^{-1}$ and $40 \mathrm{~kg} \mathrm{ha}^{-1}$ recorded 82.8 and 93.9\% higher seed cotton yield than $0 \mathrm{~kg} \mathrm{P}_{2} \mathrm{O}_{5}$ $\mathrm{ha}^{-1}$, respectively. Higher seed cotton yield obtained in higher level of phosphorous which might be due to the promotion effect of $\mathrm{P}$ fertilization on growth parameters like plant height, number of branches and leaf area index was attributed to better development of root system and nutrient absorption led to higher yield attributes. The increases in dry weight due to $\mathrm{P}$ application may be attributable to the fact that $\mathrm{P}$ is known to help in the development of more extensive root system and nodulation, and thus enables plants to absorb more water and nutrients from depth of the soil. This in turn could enhance the plant's ability to produce more assimilates which were reflected in the high seed cotton yield. Similar results have been reported by El-Habbasha et al., (2005) and Gobarah et al., (2006). The interaction effect between fly ash and phosphorous doses on seed cotton yield was also found to be nonsignificant.

Data pertaining to stalk yield of $\mathrm{Bt}$ cotton have been given in Table 3. The data indicated that the stalk yield of $\mathrm{Bt}$ cotton influenced by the fly ash doses. The highest stalk yield was recorded with the application of fly ash @ 10 t/ha which was significantly higher over the control. With application of fly ash recorded $11.1 \%$ more stalk yield than control. This might be resulted from more 
plant height, more number of branches per plant, more dry matter production ultimately increased the stalk yield in Bt cotton. Similar results were also reported by Saini et al (2010).

The different doses of phosphorous also affect the stalk yield of $\mathrm{Bt}$ cotton. Amongst the different phosphorous doses, the highest stalk yield was recorded in $40 \mathrm{~kg} \mathrm{P}_{2} \mathrm{O}_{5} / \mathrm{ha}$ (29.1 $\mathrm{q} / \mathrm{ha}$ ) over the $0 \mathrm{~kg} \mathrm{P}_{2} \mathrm{O}_{5} / \mathrm{ha}$ (18.6 q/ha) and 20 $\mathrm{kg} \mathrm{P}_{2} \mathrm{O}_{5} /$ ha $(24.6 \mathrm{q} / \mathrm{ha})$, but it was statistically at par with $30 \mathrm{~kg} \mathrm{P}_{2} \mathrm{O}_{5} / \mathrm{ha}(27.1 \mathrm{q} / \mathrm{ha})$. With application of $40 \mathrm{~kg} \mathrm{P}_{2} \mathrm{O}_{5} /$ ha recorded 56.4, 18.3 and $7.4 \%$ more stalk yield than control, $20 \mathrm{~kg} \quad \mathrm{P}_{2} \mathrm{O}_{5} / \mathrm{ha}$ and $30 \mathrm{~kg} \quad \mathrm{P}_{2} \mathrm{O}_{5} / \mathrm{ha}$, respectively. The interaction between fly ash and phosphorous doses was also found nonsignificant effect on stalk yield of Bt cotton.

The data related to biological yield of $\mathrm{Bt}$ cotton have been presented in Table. 3 The data indicated that the biological yield of $\mathrm{Bt}$ cotton significantly influenced by the fly ash application. The highest biological yield was recorded in fly ash @ 10 t/ha. With application of fly ash recorded $9.32 \%$ more biological yield than control. Amongst the different phosphorous doses, the highest biological yield was recorded in $40 \mathrm{~kg}$ $\mathrm{P}_{2} \mathrm{O}_{5} /$ ha which was significantly higher over the control, 20 and $30 \mathrm{~kg} \mathrm{P}_{2} \mathrm{O}_{5} / \mathrm{ha}$. With application of $40 \mathrm{~kg} \mathrm{P}_{2} \mathrm{O}_{5} / \mathrm{ha}$ recorded 69.1 , 21.1 and $6.63 \%$ more biological yield than control, $20 \mathrm{~kg} \mathrm{P}_{2} \mathrm{O}_{5} / \mathrm{ha}$ and $30 \mathrm{~kg} \mathrm{P}_{2} \mathrm{O}_{5} / \mathrm{ha}$, respectively. The interaction effect between fly ash and phosphorous doses on biological yield of Bt cotton was found to be nonsignificant.

The data regarding harvest index have been presented in Table 3 indicated that application of fly ash had no effect on harvest index. Amongst the phosphorous doses, the highest harvest index was recorded in $30 \mathrm{~kg} \mathrm{P}_{2} \mathrm{O}_{5} / \mathrm{ha}$, which was significantly higher than control,
$20 \mathrm{~kg} \mathrm{P}_{2} \mathrm{O}_{5} / \mathrm{ha}$ and it was at par with $40 \mathrm{~kg}$ $\mathrm{P}_{2} \mathrm{O}_{5} /$ ha. The interaction effect between fly ash and phosphorous doses found to be nonsignificant.

It is clearly concluded that there is a good scope of increasing crop yields through the use of fly ash. It is extremely important for sustaining production and improving the fertility of soils. Fly ash significantly increased the plant growth viz., dry matter and leaf area index and yield attributing characters viz., number of sympodial branches and number of bolls and seed cotton yield, stalk yield and biological yield in Bt cotton. Application of fly ash @ 10 t/ha recorded $6.62 \%$ more seed cotton yield than control. Phosphorous $\left(\mathrm{P}_{2} \mathrm{O}_{5}\right) @ 30 \mathrm{~kg} \mathrm{ha}^{-1}$ and $40 \mathrm{~kg}$ $\mathrm{ha}^{-1}$ Phosphorous@30 kg $\mathrm{P}_{2} \mathrm{O}_{5} \mathrm{ha}^{-1}$ and 40 $\mathrm{kg} \mathrm{P}_{2} \mathrm{O}_{5} \mathrm{ha}^{-1}$ resulted in the statistically similar plant growth, yield attributes, seed cotton yield, stalk and biological yields in Bt cotton. Phosphorous @ $30 \mathrm{~kg} \mathrm{P}_{2} \mathrm{O}_{5} \mathrm{ha}^{-1}$ and $40 \mathrm{~kg} \mathrm{P}_{2} \mathrm{O}_{5} \mathrm{ha}^{-1}$ recorded 82.8 and $93.9 \%$ higher seed cotton yield than $0 \mathrm{~kg} \mathrm{P}_{2} \mathrm{O}_{5} \mathrm{ha}^{-1}$, respectively.

\section{References}

Anonymous (2018a) Area, production and productivity of cotton in India. Cotton Advisory Board, pp. 75-82

Anonymous (2018b) Executive summary cotton crop survey 2017-18. pp. 1-42.

Anonymous (2019a) Ministry of Agriculture, Govt.of India. www.indiastat.com.

Anonymous (2019b) Package of practices for Rabi crops of Punjab. Pp. 22-24. Punjab Agricultural University, Ludhiana.

Bhuiyan M, Rahman M, Afroze F, Sutradhar G, Bhuiyan M. (2008) Effect of phosphorus, molybdenum and Rhizobium inoculation on growth and nodulation of mungbean. $J$ Soil. Nature. 2(2):25-30.

Biswas P, Bhowmick M, Bhattacharya A. (2009) Effect of molybdenum and seed inoculation on nodulation, growth and yield in urdbean [Vigna mungo (L.) Hepper]. Journal of 
Crop and Weed. 5(1):141-144.

Brady, N. C. and Weil, R. R. (2002). The Nature and Properties of Soils (13th Ed.), Pearson Education Pvt. Ltd., Indian Branch, Singapore. $311 \mathrm{pp}$

Deshmukh, Anjali., Matte, D.B. and Bhaisare, B. (2000). Soil properties as influenced by fly ash application. Journal. Soils \& Crops, 10: 69-71.

El-Habbasha, S. F. A. A. Kandil, N. S. AbuHagaza, A. K. Abd-El-Haleem, M. A. Khalfallah and T. Gh. Behairy (2005) Effect of phosphorus levels and some bio fertilizers on dry matter, yield and yield attributes of groundnut, Bulletin of Faculty of Agriculture, Cairo University, 56: 237252.

Gobarah, M E, Mohammad M H and Tawfik M M (2006) Effect of phosphorus fertilizer and foliar spraying with zinc on growth, yield and quality of groundnut under reclaimed sandy soils", Journal of Applied Science Research, Pakistan 2: 91-496.

Khan MMS, Singh VP and Kumar A. (2017) Studies on Effect of Phosphorous Levels on Growth and Yield of Kharif Mung bean (Vigna radiata L. wilczek). International Journal of Pure and Applied Biological Sciences. 5(4):800-808.

Kuchanwar O D and Matte D B (1997) Study of graded doses of fly ash and fertilizers on growth and yield of groundnut (Arachis hypogaea). J soils Crops 7: 36-38.

Kuchanwar, O. D, Matte, D. B. and Kene, D. R. (1997) Evaluation of graded doses of fly ash and fertilizers on nutrient content and uptake of groundnut grown on vertisol. $J$. Soil Pollut. 87: 93-110.

Matte, D B and Kene, D R (1995) Effect of fly ash application on yield performance of Kharif and Rabi crops. Journal of Soils and Crops,5(2):133-36.
Nadeem MA, Ahmad R and Ahmad MS. (2004) Effect of seed inoculation and different fertilizer levels on the growth and yield of mungbean (Vigna radiata L.). J Agron.; 3(1):40-42.

Rautoray, S. K. Swain, D.K. and Ghosh, B C (2009) Direct and residual effect of fly ash, organic materials and mineral fertilizers on performance of rice based cropping system under acid lateritic soil conditions. Asian Journal of Water, Environment and Pollution.6(1): 59-65.

Saini, S P, Manchanda, J S, Kansal, B D and Arora, C L (2010) Effect of fly ash and FYM application on yield and macro and micronutrients availability to rice. Environmental Economics. 28(2): 923-29.

Sepat S. (2005) Response of mothbean [Vigna aconitifolia (Jacq.) Marechal] to phosphorus and sulphur fertilization under rainfed conditions M. Sc. (Ag.) Thesis, Rajasthan Agricultural University, Bikaner.

Singh J, Rao M R, K Punit Mohan and Mayee C D (2006).Impact of soil depths on yield of $\mathrm{Bt}$ cotton hybrids under rainfed conditions. Journal of Cotton Research and Development 20(1):80-82.

Singh N B and Singh M (1986) Effect of fly ash application on saline soil mid on yield components and uptake of NPK of rice and wheat at varying fertility levels. Ann Agri Res 7: 245-57.

Singh N B and Singh M (1986) Effect of fly ash application on saline soil mid on yield components and uptake of NPK of rice and wheat at varying fertility levels. Ann Agri Res 7: 245-57.

Tomar, T S and Ponia, S (1992) Response of mustard (Brassica juncea) to nitrogen and phosphorus and sulphur fertilization. Indian Journal of Agronomy 42: 148 - 151.

\section{How to cite this article:}

Inderpreet Singh, Balwinder Singh Dhillon and Mandeep Kaur. 2021. Effect of Fly Ash and Phosphorus on Growth and Yield of Bt Cotton (Gossypium hirustum L.). Int.J.Curr.Microbiol.App.Sci. 10(01): 2601-2609. doi: https://doi.org/10.20546/ijcmas.2021.1001.303 